\title{
Journalism, Public Relations, and Spin
}

\author{
Jim Macnamara
}

The efficacy of journalism in performing its role in society, particularly the important role of independent journalism in a democracy discussed in Chapter 20, is impacted by a number of social interactions that influence what can be called the 'social construction of journalism'. Beyond internal values, rituals, routines, and practices and beyond the economic, political, and technological contexts of journalism, which are all important as shown in this handbook, journalism is fundamentally shaped and influenced by who journalists talk to - their sources of information and influence (Manning, 2001; Sigal, 1986), as discussed in Chapter 11.

In addition to primary sources, an increasing collective source of information and influence is the growing field of public relations and its related and largely synonymous practices. Here the term public relations, and PR for short, are used to include practices referred to as corporate communication, communication management, public affairs, and government and political communication. All of these organizational functions fit the parsimonious definition of PR as "the management of communication between an organization and its publics" (Grunig \& Hunt, 1984, p. 6).

Journalism and PR have long co-existed and undergone what Schönhagen and Meißner (2016) call "co-evolution". As identified by Dinan and Miller (2009) in the first edition of this handbook, there have been a number of studies of this inter-relationship over the past 100 years. However, major economic and technological changes in the mediascape over the past decade and continuing tensions and even controversy because of association of PR with 'spin' warrant ongoing critical examination of this triumvirate.

\section{THE 'DECLINE’ OF JOURNALISM AND THE RISE AND RISE OF PR}

While print and broadcast journalism are still primary channels for news and information in some countries such as India and parts of south-east Asia and China, the media environment 
in many countries is characterized by decreasing numbers of journalists caused by collapsing media business models and proliferating channels for public communication due to the internet and related technologies of content production - what Western scholars refer to as the 'crisis in journalism' (Curran, 2010; Jones, 2011). For example, despite growth in the total circulation of newspapers worldwide, total newspaper revenue globally fell by 2.1 per cent in 2016 and was down by 7.8 per cent over the previous five years. Print advertising revenue declined by 8 per cent in 2016 and, while digital advertising grew, its 5 per cent increase did not offset overall media losses (WAN-IFRA, 2017, p. 7). Notwithstanding alternative revenue streams such as audience revenue through subscriptions and investment in publicly funded media in some countries, this trend is undermining journalism.

In this depleted public sphere, the potential influence of PR has escalated over the past few decades far beyond what the press agents of the early twentieth century would have ever imagined or dreamed. Even in countries in which journalism enjoys public and financial support PR is growing. Industry tracking studies report that expenditure on PR by corporations, governments, non-government organizations (NGOs) and even non-profit entities is growing by 10 per cent a year on average and by up to 20 per cent a year in fastdeveloping countries (ICCO, 2013). In 2016, an annual study published by The Holmes Report in conjunction with the USC Annenberg Center for Public Relations estimated the value of the PR industry globally at US\$15 billion (Holmes Report, 2016). However, this is conservative and even misleading, as the UK PR Consultants Association estimated that spending on PR in the UK grew by 34 per cent between 2013 and 2016 to almost $£ 13$ billion a year (US\$17 billion) (PRCA, 2017). As PR expenditure is mainly tracked through the annual financial reports and rankings of agencies, with government and corporations not revealing their expenditure on PR, it is likely that global spending on PR is more than US\$50 billion a year.

Media and communication schools in universities in the USA, UK, Europe and many other countries have burgeoning PR courses that have become 'cash cows', often propping up struggling journalism programs (Bovet (1992). These developments have caused concern among scholars and industry leaders in journalism as well as political scientists and sociologists concerned about maintaining a viable public sphere in democratic societies and emerging democracies ${ }^{1}$. 
Even though the deliberative public sphere envisaged by Habermas $(1989,2006)$ as a mediated environment in which citizens can be become informed and engage in rational critical debate is seen by many as idealistic (Curran, 2002; Dahlgren, 2009), the central concept continues to be viewed as fundamental for the operation of democracy and civil society. 'Promotional culture' (Wernick, 1991) and persuasion on behalf of vested interests and elites, in which PR practitioners are identified as key actors (Miller, 1989; Negus, 2002), are seen by critical scholars as undermining and contaminating the public sphere.

Early theories and models of PR such as press agentry and one-way informational and persuasion approaches (Grunig \& Hunt, 1984) contributed to this concern. More recently, PR has been theorized as two-way and even symmetrical interaction and engagement between organizations and their publics (J. Grunig, L. Grunig, \& Dozier, 2006) and as dialogue (Taylor \& Kent, 2014). However, critical PR and communication scholars cite such models as normative (Kent \& Taylor, 2007; Laskin, 2012) and argue that PR is mostly engaged to represent the interests of corporate, government and political power elites using techniques of persuasion and sometimes 'spin' (Berger \& Reber, 2006; Miller \& Dinan, 2007). Even when carried out ethically and with corporate social responsibility (CSR), PR represents particular interests, whereas journalism has a responsibility to be bipartisan, critical, and represent alternative interests. It should not be surprising then that the two fields have a tensioned relationship.

There have been somewhere between 150 and 200 studies of the interrelationship between journalism and PR during the past 100 years (Sallot \& Johnson, 2006; Macnamara, 2014). One might presume that, as a result, there is a clear understanding of the interrelationship and its effects. However, studies show the interrelationship between journalism and PR to be paradoxical and largely misrepresented through stereotyping and discourses that, as Foucault (1972) cautioned, need to be unpacked because of how they both create and distort reality. Furthermore, new technologies, particularly the internet and social media, have brought changes to both sectors (Lloyd \& Toogood, 2015). To a large extent, these technologies have brought challenges to journalism through audience fragmentation (Jenkins, 2006; Rosen, 2006) and opportunities to PR through social media channels and the removal of media 'gatekeepers' (White, 1950) ${ }^{2}$ - thus potentially increasing the influence of PR and the tensions between journalism and PR. Therefore, continuing research into the interrelationship between journalism and PR is warranted as well as understanding of historical interactions and influences. 


\section{THE INFLUENCE OF PR}

\section{$P R$ in the twentieth century}

In a history of American journalism, Bleyer (1973) reported that even before World War I the "system of supplying newspapers with publicity and propaganda in the guise of news became so popular that a census of accredited press agents" was conducted by New York newspapers (p. 421). This identified around 1,200 press agents, a popular term at the time, working to influence public opinion through mass media in the early 1900s. Another historical review by Bird and Merwin (1955) reported that newspapers "faced a choice between accepting the releases of press agents, or failing to report many facts needed for the record" (p. 521).

A number of studies of the influence of PR, referred to as press agentry and increasingly as publicity, media relations and public relations, were conducted through the twentieth century, each showing substantial and growing influence of PR. For instance, a 1926 study of The New York Times found 147 of the 256 news stories in the newspaper (57 per cent) had been suggested, created or supplied by PR practitioners (Bent, 1927). Another early twentieth century study by Bixler (1930) concluded that women's pages in newspapers were almost totally dependent on publicists and that many stories in business sections were also heavily influenced by these early PR practitioners. In 1934, Walker identified that 42 of 64 local stories in one newspaper "were written or pasted up from press agent material: a little more than 60 per cent" (1999, p. 147).

In the second half of the twentieth century, a number of studies consistently showed PR to a significant and growing influence on mass media content and raised concerns about this trend. Noteworthy among these were analyses by Sigal in 1973 and Gans in 1979. Sigal's study of 1,146 stories in The Washington Post and The New York Times found that 75 per cent resulted from what he called "information processing" compared with proactively researched information. Around two-thirds of media stories were found to have originated from news releases and other documents handed to reporters by news sources, increasingly through PR practitioners (Sigal, 1973; Grossberg, Wartella, Whitney \& Wise, 2006, p. 352). The widely-reported content analysis of US national TV news and news magazines by Gans (1979) found that 75 per cent of all news came from government and commercial sources and much if not most of this could be classified as PR. 
Gans was also one of the first to examine specific 'beats' or 'rounds' such as business and finance, crime, transport, entertainment, travel, and sports reporting. He noted that "beat reporters are drawn into a symbiotic relationship of mutual obligation with their sources, which both facilitates and complicates their work" (1979, p. 133). For instance, a content analysis of health reporting in major US newspapers in 1979-80 by Brown, Bybee, Wearden and Straughan (1987) found that 80 per cent of wire service stories relied on official proceedings (e.g., of conferences and seminars), press releases and press conferences. A number of other studies during this period consistently found 50 to 80 per cent of newspaper, radio, TV, and wire service content sourced from PR, such as those of Abbott and Brassfield (1989), Sachsman (1976), Turk (1986), and Grossberg et al (2006).

Research in Europe has gained similar findings, such as that by Baerns in the 1970s and 1980s, which found journalists are heavily influenced by PR in terms of both topics and timing (as cited in Bentele \& Nothhaft, 2008, p. 34). Similarly, several studies in Australia in the 1990s found PR content in news media content ranging from almost 40 per cent to 70 per cent. For instance, based on content analysis of more than 1,000 articles in Australia's three leading capital city newspapers, Zawawi $(1994,2001)$ found that 37 per cent were directly the result of PR. Furthermore, Zawawi argued that reports, papers, and submissions sent to journalists by organizations could also be regarded as PR and these took PR-influenced media content to 47 per cent.

\section{PR-ization of media in the twenty-first century}

Studies of the influence of PR on media continued in the early twenty-first century. For example, Sallot and Johnson (2006) analysed 413 reports of interviews with US journalists conducted between 1991 and 2004 and found that, on average, journalists estimated that 44 per cent of the content of US news media was the result of PR contact. Journalists' estimates could be expected to be conservative, given frequent denials of PR influence and negative attitudes towards PR as discussed in the next section.

In the UK, an extensive 2008 study of 2,207 newspaper articles and 402 radio and TV reports spanning crime, politics, business, health and entertainment conducted by Cardiff University found that 60 per cent of the content of Britain's leading newspapers and 34 per cent of broadcast stories were comprised wholly of wire service copy or PR material. The study reported that "a further 13 per cent of press articles and six per cent of broadcast news items 
were unconfirmed but categorized as 'looks like PR'. In other words, the Cardiff University study suggested that more than half of the content of leading British newspapers and broadcast networks was influenced by PR in some way. The researchers reported that only 12 per cent of British press articles could be established to be entirely independent (Lewis, Williams, Franklin, Thomas, \& Mosdell, 2008).

Recent studies in Australia and New Zealand, such as a 2010 analysis by the Australian Centre for Independent Journalism at the University of Technology Sydney ("Over half of your news is spin", 2010) and a 2011 project involving ethnography in two newsrooms in New Zealand by Sissons (2012) have continued to report high reliance on PR. Sissons concluded that "journalists are in many instances not carrying out the traditional practice of checking information. Instead, journalists appear to be replicating the material given to them by public relations professionals" (p. 274). From extensive empirical data, it can be concluded that between 30 and 80 per cent of media content is sourced from or significantly influenced by PR, with estimates of 50-75 per cent common, with the range related to variations between types of media (e.g., general news, 'rounds', trade media, etc.). In Flat Earth News, Davies refers to this phenomenon as churnalism.

\section{THE DISCOURSE OF DENIAL}

Despite the overwhelming evidence available from studies such as those cited, a longmaintained response within journalism has been a discourse of denial in relation to using PR outputs, referred to by Gandy (1982) as “information subsidies". In an historical analysis reviewing journalists' attitudes towards PR, DeLorme and Fedler (2003) concluded that journalists rarely acknowledge PR practitioners' contributions. Davies similarly noted in his discussion of PR contributing to churnalism that "newspapers do not admit to this" $(2009, \mathrm{p}$. 52). Australian media researcher Graeme Turner also concluded that "journalists, for their part, tend to deny that public relations activities have much influence on what they print" (2010, p. 212) - what McChesney calls "the dirty secret of journalism" (2013,p. 90). The discourse of denial in relation to PR is shown by extensive research to be unfounded and fallacious and has long allowed PR to be "the invisible hand" behind much of the news (Cadzow, 2001). In his critical study of twenty-first media and the internet, McChesney laments somewhat despondently that news is "increasingly ... unfiltered public relations generated surreptitiously by corporations and governments in a manner that would make Walter Lippman - whose vision guided the creation of professional journalism in the $1920 \mathrm{~s}-$ 
roll in his grave" (2013, p. 183). Thus, there is a substantial paradox at the centre of the interrelationship between journalism and PR: journalism uses a substantial amount of PR material and is influenced by PR, but this is swept under the carpet and often flatly denied.

\section{PR VS. 'SPIN'}

This paradox is partly explained by a second dominant discourse in relation to PR - the pejorative labelling of PR as 'spin' (Burton, 2007; Ewen, 1996) and PR practitioners as 'spin doctors' (Ewen, 1996). While the term 'spin' originated in politics, it is now widely applied to corporate and government PR as well as political communication, with its sinister implications of twisting and fabrication derived from its original reference to yarn and fabrics (Andrews, 2006). Dozens of books and hundreds of articles have been written about PR as spin, notable among them Ewen's (1996) PR: A Social History of Spin; The Father of Spin: Edward L. Bernays and the Birth of Public Relations (Tye, 1998), and Inside Spin: The Dark Underbelly of the PR Industry (Burton, 2007).

Discussion of PR in journalism texts and popular discourse would lead one to believe that the terms PR and spin are synonymous and that the title of this chapter referring to public relations and spin is largely tautological. While some PR protagonists argue that journalism and PR are "mutually dependent/interdependent" (Erjavec, 2005; Gieber \& Johnson, 1961) and even "symbiotic" (Bentele \& Nothhaft, 2008; Currah, 2009), research shows a long history of tension and even antipathy among journalists towards PR (Delorme \& Fedler, 2003; Jeffers, 1977; Kopenhaver, 1985; Kopenhaver, Martinson, \& Ryan, 1984; Ryan \& Martinson, 1988; Stegall \& Sanders, 1986; White \& Shaw, 2005; Wilson \& Supa, 2013).

As well as generalizing PR pejoratively as 'spin', journalism scholars and commentators accuse PR of corrupting the media and the public sphere with pseudo-events, pseudoevidence, pseudo-groups, pseudo-leaks, pseudo-pictures and even pseudo-illnesses (Davies, 2009, pp. 172-193). Over the past 75 years, PR also has been referred to as "hype", "puff”, "ballyhoo", "bunco", "boosterism", “cover up" and "propaganda" and PR practitioners have been labelled "flacks", "fabricators", "fakers and phonies", "shysters", "obstructionists" "liars" and "spinmeisters" (Macnamara, 2014, pp. 7-8). In an historical review of journalistPR relations, DeLorme and Fedler concluded that the relationship is "tense and complex" (Delorme \& Fedler, 2003, p. 101). In a New Zealand study, Tilley and Hollings described the 
interaction as a "love-hate relationship" (2008, p. 1) - a view echoed by Harcup (2009) in a contemporary UK journalism text.

While naming PR as spin seems to suggest transparency and critique, in reality it achieves the opposite as it generalizes, marginalizes, and trivializes PR. The term spin is applied so broadly that, like all generalizations, it masks diversity and presents a falsely coherent, unified view of PR that is a stereotype. Furthermore, while being demonized, spin is also marginalized and trivialized as something that is innocuous and not worthy of serious attention because journalists allegedly avoid or reject it. Such rhetorical techniques and discourses lull media consumers - and perhaps journalists themselves - into a false sense of security. As Atkinson (2005) concluded in relation to political PR: "demonized spin is a derogatory form of news discourse where journalists pose as heroic fighters against manipulative politicians and their staffs" when, in reality, research shows "glaring blindspots" in relation to "the media's own contributory role" in spin (pp. 17-18).

One of the blindspots referred to is that PR practitioners report that they are regularly contacted by journalists asking for information and content (Macnamara, 2014; Waters, Tindall \& Morton, 2010). Also, a number of studies show that PR material is often used by journalists little changed or even verbatim (Davies, 2009; Lewis et al., 2008; Macnamara, 1993). Some journalism texts acknowledge that many PR professionals are "honest brokers of information" (Hohenberg, 1973, p. 351), who act as intermediaries between media and organizations and also between organizations and their stakeholders and publics. As noted previously, some claim that the two fields are "mutually dependent/interdependent" (Erjavec, 2005; Gieber \& Johnson, 1961), “symbiotic” (Bentele \& Nothhaft, 2008; Currah, 2009), or "two sides of the same coin" (Evans, 2010, p. 31).

In such an environment of conflicting claims, a more informed and nuanced understanding of the functions as well as the dysfunctions of PR, and its interrelationship with journalism, rather than reliance on media myths and internecine industry feuding, is essential for the production of independent journalism and a healthy public sphere that can serve to create an informed society, while at the same time allowing freedom of speech. 


\section{CONTEMPORARY RESEARCH INSIGHTS}

Contemporary research shows a continuation of the co-existence and blurring of journalism and PR - and also advertising to some extent. The 2018 Global Communications Report published by the University of Southern California, Annenberg revealed that 64 per cent of more than 1,000 senior PR professionals surveyed believe that the average media consumer will not be able to tell the difference between paid, earned, shared and owned media (referred to as the PESO model of media) within the next the next five years (USC Annenberg, 2018, p. 17). In recent years, the European Communication Monitor (Zerfass, Verčič, Verhoeven, Moreno, \& Tench, 2015), based on a survey of more than 2,000 European PR and communication professionals, and the Asia-Pacific Communication Monitor (Macnamara, Lwin, Adi, \& Zerfass, 2015, 2016, 2017), based on a survey of more than 1,200 practitioners, also have identified a collapse of traditional boundaries between paid (advertising), earned (editorial), shared (social) and owned (corporate) media.

Recent research has highlighted new developments that are expanding this blurred 'grey zone' between paid, earned and owned media content, such as native advertising, content marketing, and brand journalism (Verčič \& Tkalac Verčič, 2016). All involve the placement of promotional messages in a format that resembles journalism and is sometimes indistinguishable. These media strategies are designed to overcome resistance to traditional advertising and to avoid persuasion knowledge - the recognition of media content as intentional attempts at persuasion, which reduces the effect of persuasion (Friestad \& Wright, 1994). While these approaches sometimes involve the bypassing of journalists through direct corporate and government publishing (e.g., on Websites), frequently they involve the cooperation of journalists and editors, particularly when media revenues are in decline. Such approaches are regarded as deceptive (de Pelsmacker \& Neijens 2012) and, thus, they raise ethical questions which, to date, have been insufficiently examined.

Meanwhile, journalists also continue to cooperate with PR practitioners in day-to-day reporting, despite the 'discourse of denial' and concerns about 'spin'. A major qualitative study undertaken in 2013-2014 cast new light and gave an updated perspective on this complex and paradoxical relationship (Macnamara, 2014). Whereas most previous studies of these issues involved surveys that are often filled out by junior employees as reported by Reichheld (2008), this study involved in-depth, face-to-face interviews with a purposive sample of 32 senior practitioners working in journalism and/or PR respectively in the UK, 
USA, Australia and Asia Pacific. The sample was selected across a range of 'rounds' and sectors including general news reporting, business and finance, politics, IT and telecommunications, transport, energy/petroleum and gas, health, food, agriculture, and consumer products and lifestyle. Several interviewees had between 30 and 35 years of experience in journalism and/or PR and one had more than 40 years professional experience. Overall, the 32 interviewees had an average of 21.5 years of experience in journalism and/or PR. A number of interviewees had experience in both journalism and PR, a not unusual occurrence due to the long-standing trend of journalists moving into PR (Lancaster, 1992), and it is considered that this enhanced the sample's insights by affording multiple and comparative perspectives.

\section{Journalists not only use PR 'handouts' but seek out PR}

Almost unanimously the senior journalists interviewed confirmed substantial use of PR material and interaction with PR practitioners. They reported that this occurs both proactively as well as reactively. For instance, UK journalist Martin Frizell, who worked for Reuters, Sky News, and ITV before becoming editor of the top-rating London morning TV program GMTV, said:

I think journalists like to put out the impression that they're getting scoops out of their own endeavours, their own originality. But a lot of the time they're not. A lot of the time they're getting things that are coming to them, referred to in the trade as handouts. (personal communication, June 24, 2013)

Former editor in chief of The Sydney Morning Herald and 35-year veteran journalist David Hickie said that his experience had been that:

Making contact with the public relations or the public affairs representative of an organization is valuable to your accuracy and to the story generally ... because a journalist may not be exactly up to date with ... the latest developments in an area. The [PR] practitioner in a specific area ... is an expert or can direct you to an expert in the organization. (personal communication, October 24, 2013) 


\section{Acculturation of PR as sources}

The co-existence of such acknowledgements and empirical data showing high usage of PR material on one hand, and a discourse of denial as well as the discourse of spin and antipathy towards PR on the other, emphasize the paradox or journalism-PR interaction and raise a puzzling question. How do journalists and editors explain and justify regularly using PR material and relying on PR contacts, while at the same time holding negative perceptions and being publicly critical of PR? Probing discussions with senior journalists and PR practitioners revealed two explanations that serve to answer this question and explain this paradox at the heart of the journalism-PR nexus.

One factor explaining why many journalists appear to lie about using PR emerged from descriptions of PR by journalists including BBC journalist turned PR practitioner Andy Winstanley who said "journalists mainly classify PR material as that given in press releases, events and news conferences". He added that "many would not classify information gained in briefings and from those they view as 'contacts' as PR material" (personal communication, September 2, 2013). Several of the other journalists interviewed also described PR in similarly narrow terms. This revealed that journalists identify some traditional media relations practices as PR, but do not recognize many other communication strategies as such. For example, much of the information on government and corporate Web sites is created by PR departments or agencies (albeit they may be called 'strategic communication' 'corporate communication' or other terms) as well as their social media communication (Peppercom/IPR, 2017). Similarly, launches and openings, exclusive interviews and visits by international VIPs, who journalists flock to meet and quote, are often conceived and arranged by PR practitioners. Winstanley's observation is a significant insight that partly explains the paradox and contradictions in journalism-PR relations and indicates that the discourse of denial is not intentional lying or deceit. While it reflects naivety in relation to PR, its root cause is a cultural interpretation of what constitutes PR framed within a narrow media-centric view that has long characterized journalism and media studies and which needs to be replaced with a broader sociological perspective, according to scholars such as Couldry (2010).

A second important insight into the long-standing paradox at the heart of journalist-PR relations was gleaned from close analysis of statements by journalists about PR practitioners generally compared with responses given in relation to PR practitioners with whom they acknowledged having regular interaction. Analysis confirmed what is referred to as the 
Jeffers' Syndrome - the finding by Jeffers (1977) that journalists view PR practitioners who they know personally more favourably than they do PR practitioners generally. Depth interviews with journalists took this finding one step further. Not only do journalists tend to more favourably perceive PR practitioners who they know and work with often compared with PR practitioners generally, but they re-categorize them within their conceptual and professional frameworks. For example, when it was pointed out to journalists that one or more of their named sources was a PR practitioner, responses included: “Oh, she's not really a PR, she's more of an industry specialist" and, in another case, "I don't know what his job title is, but he's an expert in the field" (personal communication, June 26-27, 2013). Andy Winstanley brought this fully into light when he said "the best PRs are actually not seen as PRs but as good contacts" (personal communication, October 8, 2013). Along with 'specialists' and 'experts', other terms used to describe these 'transported' PR practitioners were "authorities" and even "trusted sources". Thus, as well as not recognizing many forms of 'information subsidies' and public communication practices as $\mathrm{PR}$, journalists are prone to exclude their positive personal interrelationships with PR practitioners from what they perceive as 'PR'.

This latter tendency was referred to and theorized in Macnamara (2014) as PR acculturation because not only do journalists adapt their view of some PR practitioners, but when relationships build up over time, they mentally remove them from the field and rubric of PR and they become acculturated into journalists' inner circle of 'contacts' and 'trusted sources'.

\section{Lack of knowledge about PR, media relations, and publicity}

While further illuminating the inter-relationship between journalism and PR, the 2014 study cited above also confirmed a misunderstanding about PR and its connection with media relations and publicity that adds a qualification and a clarification to these findings. Journalists and journalism scholars frequently view PR as solely focused on influencing journalists to gain media publicity. This conflation of PR with media relations and publicity leads to a defensive attitude among many journalists and journalism researchers who point to the size of the PR industry and its global growth as evidence of a powerful behemoth targeting a declining number of overworked journalists. For example, in a journalism text book, Lamble says: "Our state and federal governments in particular, but also many local governments, employ small armies of public relations staff and media advisers: 'minders' whose sole responsibility is to do their utmost to portray their governments to the public" 
(2011, p. 77). The role of PR is described by Lamble as "blowing their own trumpets" and "targeting journalists with a deluge of media releases and deflecting criticism". Ironically, the same section adds: "But on the positive side, media releases can sometimes provide great story leads" (Lamble, 2011, pp. 77-78), illustrating the noted paradox and potentially a double standard.

In reality, PR is a broad field of practice that typically includes producing content for web sites; managing organizational social media sites; producing publications such as annual reports, newsletters and brochures; managing events such as launches, trade shows, and conferences; and specialist communication roles such as employee communication, shareholder/investor relations, and community relations (Broom \& Sha, 2013; Macnamara, 2012; Wilcox \& Cameron, 2010). Many PR professionals have little or no contact with journalists. Therefore, generalizations about the influence of PR on journalism are misleading and should be avoided.

\section{THE ‘FOURTH MEDIA REVOLUTION’ - SOCIAL MEDIA}

The shift from traditional to social media is increasing in PR practice as well as among journalists, along with the use of owned media for digital publishing. Hence, social media and social networks deserve specific attention in any contemporary discussion of the relationship between PR and journalism.

The internet, particularly web sites, blogs and social media such as Facebook, Twitter, YouTube, Sina Weibo and Renren in China, Tumblr, and others, have given journalists new opportunities for research, source acquisition and contact, and publishing. While some journalists initially resisted social media, seeing them as competitors, many journalists now embrace social media and an increasing number of media publish only online. A notable example of this new type of media is The Huffington Post, which won a Pulitzer Prize in 2012 for an series on wounded veterans written by David Wood ("2012 journalism Pulitzer winners", 2012).

Social media are part of what Poster (1995) called the 'second media age' and what other media scholars refer to as the "fourth media revolution" after creation of the alphabet which enabled writing, invention of the printing press, and development of broadcasting (Balnaves, Donald, \& Shoesmith, 2009, p. 12). 
As well as changing the mediascape for journalists and citizens, social media also have further expanded the channels of communication available to PR, which is emphasized in the notion of "PR 2.0" that is enthusiastically discussed in PR literature such as in Breakenridge's (2008) book, PR 2.0: New Media, New Tools, New Audiences.

A US study by Hazelton, Harrison-Rexrode, and Keenan claims that PR is "undergoing a revolution" because of social media (2008, p. 91). In the foreword of Breakenridge (2008), social media advocate Brian Solis effuses: "Welcome to what just may be the greatest evolution in the history of PR" (Solis, 2008, p. xvii). In the title of another book, Solis and Breakenridge (2009) claim that Web 2.0 is "putting the public back in public relations". Similarly, in Corporate Communication: A Guide to Theory and Practice, Cornelissen (2011) states that social media "create new ways of reaching and engaging with stakeholders". He adds that the development of new media "provides an organization with the opportunity to engage in conversations and to tell and elaborate its story or key message to stakeholders or the general public in an interactive way" (2011, p. 154).

PR practitioners use various forms of social media and other digital communication to bypass journalists including Web sites, blogs, e-newsletters and social networks such as Facebook, RenRen, Twitter, Weibo, Instagram, YouTube, and Youku. These channels represent what has been referred to as "a world where everyone is a publisher, no one is an editor" (Pelley, n.d.).

Editors, journalists and academics have raised concerns about social media content which bypasses the 'gatekeepers' who operate in traditional media (White, 1950) - the editors, subeditors, and fact checkers who verify sources and confirm the veracity of statements and claims made. The directness of digital and social media communication means that PR practitioners can potentially distribute 'spin' and even 'fake news' without the intervention of traditional intermediaries.

In addition, social networks and social media are increasingly engaged in the ongoing interaction between PR and journalism and are changing the methods of journalism-PR interaction, but not the interdependence. For example, traditional media releases (also still referred to as 'press releases') are increasingly giving way to social media releases. Former Financial Times journalist Tom Foremski declared in a widely-quoted 2006 blog post: "Die! 
Press release! Die! Die! Die!” Foremski (2006) called for a new format for information supplied to media. In response, PR practitioners have argued that media releases are not dead, but that a new kind of media release is required in the era of digital and social media. One who has led this debate online is social media expert and author of the blog PR-Squared, Todd Defren, who has published a template for a social media release (Defren, 2008). Social media releases are much more than media releases sent to new types of social media. Defren recommends that all information provided to media should be a social media release. The key features of social media releases proposed by Defren include a short bullet-point format rather than long text; inclusion of hyperlinks for further information; use of graphics for easy navigation and visual appeal; inclusion of JPEG photographs and MP3 sound files as well as video; and links to the organization's social media sites.

Beyond their own digital sites and using social networks and media to communicate with journalists, today almost all organizations including government departments and agencies, non-government organizations such as museums and other public institutions, and non-profit groups such as charities participate in public social media, both with their own pages and profiles as well as in open online discussion and debate.

Because of these developments, concern continues to be expressed that PR exerts an undue and unhealthy influence over news and public debate. For example, in a recent study of German media, Koch, Obermaier and Riesmeyer (2017) noted that journalists and PR practitioners depend on each other, but argued that still "there are many unanswered questions about how public relations exerts power over journalists and how these influence attempts may affect news coverage" (2017, n. p.).

One answer that can be drawn from the large body of research indicating substantial and growing influence of PR is that the field of public relations needs more than ever to focus on ethical behaviour and social responsibility in its activities. There are signs that this is occurring. Beyond the claims of professional PR bodies, an independent study in the UK by Jackson and Maloney (2016) concluded:

Despite many circumstances working in their favour, this does not mean they necessary feel emboldened in their everyday encounters with journalists ... very few observe journalists' recent travails with glee: most want to see a robust and independent journalism where PR input is balanced with other sources. (2016, p. 753) 


\section{LOOKING TO THE FUTURE}

Given the importance of news, information and channels for public debate in democratic societies in particular, it can be concluded that there is a need to do more in research, education, and professional practice. Four key conclusions emerge from historical and recent research, which serve as pointers to future directions in the problematic and paradoxical interrelationship between journalism and PR.

\section{Transparency}

There remains a need for greater transparency in both journalism and PR, rather than the 'discourse of denial' that has prevailed among journalists and the 'trade secrets' of PR in relation to ways that it influences news media and public debate. One suggestion put forward by the UK Media Standards Trust (2018) as part of its Transparency Initiative is for declaration of the sources of all paid and subsidized content including PR material used without corroborating evidence. While most editors and journalists reject such calls (Macnamara 2014), in an era of 'fake news' and 'post truth', greater transparency will be essential to maintain public trust.

\section{Educating journalists}

The 'discourse of denial' in relation to PR and misunderstandings revealed in research indicate that journalism education needs to include development of knowledge about PR. While 'academic wars' have occurred and continue in some institutions between the fields of journalism, mass communication and PR (White \& Shaw, 2005; Wright, 2005), education about PR will increase journalists' ability to identify, analyse and critically evaluate PR messages, which Holladay and Coombs (2013) refer to as "public relations literacy", as well as disrupt stereotypes and prejudices based on misunderstanding and myths.

\section{Educating PR practitioners in ethics and social responsibility}

On the other side of the equation, critical PR studies support the case for more ethics training of PR practitioners. A survey of more than 1,800 PR practitioners in North America, Australia, New Zealand and the Middle East found that 70 per cent had not received any 
training in ethics" (Bowen \& Heath, 2006, p. 34) and a 2014 analysis by Fawkes concluded that PR ethics is "often incoherent and aspirational rather than grounded in ... practice" (2014, p. 8). Also, the concept of social responsibility should be expanded to address the expanded role of PR practitioners in the contemporary public sphere through social media and digital communication including the practices of native advertising, content marketing and brand journalism. Given the criticisms of PR and the all too frequent public controversies in relation to PR reported in the media and academic literature, education of PR practitioners requires both academic attention in PR courses as well as ongoing professional development in the industry.

\section{Further research}

Emerging media practices such as native advertising, content marketing and brand journalism require further research, particularly in relation to ethics and the public interest. Also, while the emerging controversy surrounding 'fake news' cannot be laid at the feet of PR practitioners, the potential of PR to contribute to such distortion of the public sphere should be addressed by PR researchers as well as media scholars, sociologists and political scientists.

Research on the relationship between journalism and PR to date has been predominantly focussed on major Western countries. For example, Domm comments that "little of the available international research has embraced the worldviews and perspectives of practitioners operating in the rapidly developing countries of South East Asia" (2016, p. 641). He reports that practitioners in Asia see Western theory and practice as having only limited applicability to their circumstances. Therefore, further study of the inter-relationship between journalism and PR in central, northern and south-east Asia, Africa, South America, and the Middle East would be informative and a useful contribution to our understanding of media and public communication.

Further research and the initiatives discussed above will contribute to maintaining independent media as key actors in the public sphere, while affording organizations freedom of speech and opportunities to engage with their stakeholders and publics in open, direct and ethical ways.

\section{REFERENCES}


2012 journalism Pulitzer winners. (2012, April 16). The New York Times. Retrieved from http://www.nytimes.com/2012/04/17/business/media/2012-Journalism-Pulitzer-Winners.html

Abbott, E., \& Brassfield, L. (1989). Comparing decisions on releases by TV and newspaper gatekeepers. Journalism Quarterly, 66(4), 853-856.

http://dx.doi.org/10.1177/107769908906600411

Andrews, L. (2006). Spin: From tactic to tabloid, Journal of Public Affairs, 6(1), 31-45. http://dx.doi.org/10.1002/pa.37

Atkinson, J. (2005). Metaspin: Demonization of media manipulation. Political Science, 57(2), 1-27. http://dx.doi.org/10.1177/003231870505700203

Balnaves, M., Donald, S., \& Shoesmith, B. (2009). Media theories and approaches: A global perspective. Basingstoke, UK: Palgrave Macmillan.

Bent, S. (1927). Ballyhoo: The voice of the press. New York: Boni \& Liveright.

Bentele, G., \& Nothhaft, H. (2008). The intereffication model: Theoretical discussions and empirical research. In A. Zerfass, B. Van Ruler, \& K. Sriramesh (Eds.), Public relations research: European and international perspectives and innovations (pp. 33-48). Wiesbaden, Germany: VS Verlag fur Sozialwissenschaften (Springer Science + Business Media).

Berger, P., \& Reber, B. (2006). Gaining influence in public relations: The role of resistance in practice. Mahwah, NJ: Lawrence Erlbaum.

Bird, G., \& Merwin, F. (Eds.). (1955). The press and society: A book of readings. New York, NY: Prentice-Hall. (Original work published 1951). Retrieved from http://archive.org/stream/pressandsociety030075mbp/pressandsociety030075mbp_djvu.txt

Bixler, P. (1930). The reporter's last stand. The North American Review, 229, January, 113-116.

Bleyer, W. (1973). Main currents in the history of American journalism. New York, NY: Da Capo Press. (Original work published 1927)

Bovet, S. (1992). Educators need to communicate better on and off campus. Public Relations Journal, $48,14-17$.

Bowen, S., \& Heath, R. (2006). Under the microscope. Communication World (January-February, pp. 34-36.

Breakenridge, D. (2008). PR 2.0: New media, new tools, new audiences. Upper Saddle River, NJ: FT Press, Pearson Education.

Broom, G., \& Sha, B. (2013). Cutlip \& Center's effective public relations (11th ed.). Boston MA: Pearson.

Brown, J., Bybee, C., Wearden, S., \& Straughan, D. (1987). Invisible power: News sources and the limits of diversity. Journalism Quarterly, 64(1), 45-54.

http://dx.doi.org/10.1177/107769908706400106

Burton, B. (2007). Inside spin: The dark underbelly of the PR industry, Crows Nest, NSW: Allen \& Unwin. 
Cadzow, J. (2001, May 26). The hidden persuaders. Sydney Morning Herald, GoodWeekend magazine, pp. 20-24.

Cornelissen, J. (2011). Corporate communication: A guide to theory and practice (3rd ed.). London, UK and Thousand Oaks, CA: Sage.

Couldry, N. (2010). Media, society, world: Social theory and digital media practice. Cambridge, UK: Polity.

Currah, A. (2009). What's happening to our news. Oxford, UK: Reuters Institute for the Study of Journalism, Oxford University. Retrieved from https://reutersinstitute.politics.ox.ac.uk/about/news/item/article/whats-happening-to-our-news.html

Curran, J. (2002), Media and Power, London, UK, Routledge.

Curran, J. (2010). Future of journalism. Journalism Studies, 11(4), 464-476. http://dx.doi.org/10.1080/14616701003722444

Dahlgren, P. (2009), Media and political engagement: Citizens, communication and cemocracy, New York, NY, Cambridge University Press.

Davies, N. (2009). Flat earth news. London, UK: Random House.

de Pelsmacker, P., \& P. Neijens. (2012). New advertising formats: How persuasion knowledge affects consumer response. Journal of Marketing Communications, 18(1), 1-4. https://doi.org/10.1080/13527266.2011.620762

Defren, T. (2008, April 18). Social media template, version 1.5. PR-Squared blog. Retrieved from http://www.pr-squared.com/index.php/2008/04/social_media_release_template

DeLorme, D., \& Fedler, F. (2003). Journalists' hostility toward public relations: An historical analysis. Public Relations Review, 29(1), 99-124. http://dx.doi.org/10.1016/S0363-8111(03)000195

Miller, D., \& Dinan, W. (2007). A century of spin: How public relations became the cutting edge of corporate power. London, UK: Pluto Press.

Dinan, W., \& Miller, D. (2009). Journalism, public relations, and spin. In K. Wahl-Jorgensen \& T. Hanitzsch (Eds.). Handbook of journalism studies (pp. 250-264). London, UK: Routledge,.

Domm, G. (2016). Public relations practice in the emerging 'powerhouses' of South East Asia: Some views from within. Public Relations Review, 42(4), 641-653.

https://doi.org/10.1016/j.pubrev.2015.10.001

Edelman. (2017). Edelman trust barometer. Global results [Web site]. Retrieved from http://www.edelman.com/global-results

Erjavec, K. (2005). Hybrid public relations news discourse. European Journal of Communication, 20(2), 155-179. http://dx.doi.org/10.1177/0267323105052295

Evans, T. (2010). We are all in PR now. British Journalism Review, 21(2), 31-36. http://dx.doi.org/10.1177/0956474810374531

Ewen, S. (1996). PR! A social history of spin. New York, NY: Basic Books. 
Fawkes, J. (2014). Public relations ethics and professionalism: The shadow of excellence. Abingdon, UK: Routledge.

Foremski, T. (2006, February 27). Die! Press release! Die! Die! Die! Silicon Valley Watcher [Weblog].Retrieved from http://www.siliconvalleywatcher.com/mt/archives/2006/02/die_press_relea.php

Foucault, M. (1972). The archaeology of knowledge and the discourse on language. New York, NY: Harper \& Row.

Friestad, M., \& Wright, P. (1994). The persuasion knowledge model: How people cope with persuasion attempts. Journal of Consumer Research, 21(1), 1-31. https://doi.org/10.1086/209380

Gandy, O. (1982). Beyond agenda setting: Information subsidies and public policy. Norwood, NJ: Ablex.

Gans, H. (1979). Deciding what's news: A study of CBS evening news, NBC nightly news, Newsweek and Time. New York, NY: Vintage.

Gieber, W., \& Johnson, W. (1961). The City Hall 'beat': A study of reporter and source roles. Journalism Quarterly, 38, 289-297. http://dx.doi.org/10.1177/107769906103800302

Grossberg, L., Wartella, E., Whitney, D., \& Wise, J. (2006). Media making: Mass media in a popular culture ( $2^{\text {nd }}$ ed.). Thousand Oaks, CA: Sage.

Grunig, J., \& Hunt, T. (1984). Managing public relations. Orlando, FL: Holt, Rinehart \& Winston.

Grunig, J., Grunig, L., \& Dozier, D. (2006). The excellence theory. In C. Botan \& V. Hazelton (Eds.), Public relations theory II (pp. 21-62). Mahwah, NJ: Lawrence Erlbaum.

Habermas, J. (1989). The structural transformation of the public sphere (T. Burger, Trans.). Cambridge, UK: Polity. (Original work published 1962 in German)

Habermas, J. (2006). Political communication in media society: Does democracy still enjoy an epistemic dimension? The impact of normative theory on empirical research. Communication Theory, 16(4), 411-426. https://doi.org/10.1111/j.1468-2885.2006.00280.x

Harcup, T. (2009). Journalism: Principles and practices (2nd ed.). London, UK: Sage.

Hohenberg, J. (1973). The professional journalist (3rd ed.). New York, NY: Holt, Rinehart \& Winston.

Holladay, S., \& Coombs, T. (2013). Public relations literacy: Developing critical consumers of public relations. Public Relations Inquiry, 2(2), 125-146. http://dx.doi.org/10.1177/2046147X13483673

ICCO [International Communications Consultancy Organization]. (2013). ICCO world report [Web site]. Retrieved from http://www.akospr.ru/wp-content/uploads/2014/01/World-Report_en.pdf

Jackson, D., \& Moloney, K. (2016). PR, journalism and power relationships in flux. Inside Journalism, 17(6), 763-780. https://doi.org/10.1080/1461670X.2015.1017597

Jeffers, D. (1977). Performance expectations as a measure of relative status of news and PR people. Journalism Quarterly, 54, 299-307. http://dx.doi.org/10.1177/107769907705400210

Jenkins, H. (2006). Convergence culture: Where old and new media collide. New York, NY: New York University Press. 
Jones, A. (2011). Losing the news: The future of the news that feeds democracy. In D. Graber (Ed.), Media power in politics (pp. 57-65). Washington, DC: CQ Press.

Kent, M., \& Taylor, M. (2007). Beyond excellence: Extending the generic approach to international public relations: The case of Bosnia. Public Relations Review, 33(1), 10-20. https://doi.org/10.1016/j.pubrev.2006.11.002

Koch, T., Obermaier, M., \& Riesmeyer, C. (2017). Powered by public relations? Mutual perceptions of PR practitioners' bases of power over journalism. Journalism. Online. https://doi.org/10.1177/1464884917726421

Kopenhaver, L. (1985). Aligning values of practitioners and journalists. Public Relations Review, 11(2), 34-42. http://dx.doi.org/10.1016/S0363-8111(82)80117-3

Kopenhaver, L., Martinson, D., \& and Ryan, M. (1984). How public relations practitioners and editors in Florida view each other. Journalism Quarterly, 61(4), 860-888. http://dx.doi.org/10.1177/107769908406100419

Lamble, S. (2011). News as it happens: An introduction to journalism. South Melbourne, Vic: Oxford University Press.

Lancaster, P. (1992). Gentlemen of the press: The life and times of an early reporter, Julian Ralph of the Sun. New York, NY: Syracuse University Press.

Laskin, A. (2012) Public relations scales: Advancing the excellence theory. Journal of Communication Management, 16(4), 355-370. https://doi.org/10.1108/13632541211278996

Lewis, J., Williams, A., Franklin, B., Thomas, J., \& Mosdell, N. (2008). The quality and independence of British journalism: Tracking the changes of 20 years. Research report. Cardiff School of Journalism, Media and Cultural Studies, Cardiff University, Wales. Retrieved from http://www.cardiff.ac.uk/jomec/research/researchgroups/journalismstudies/fundedprojects/qualityp ress.html

Lincoln, Y., \& Guba, E. (1985). Naturalistic inquiry. Beverly Hills, CA: Sage.

Lloyd, J., \& Toogood, L. (2015). Journalism and PR: News media and public relations in the digital age. London, UK: Tauris.

Macnamara, J. (1993). Public relations and the media. Unpublished Master of Arts by research thesis, Deakin University, Geelong, Vic, Australia.

Macnamara, J. (2012). Public relations: Theories, practices, critiques. Frenchs Forest, NSW: Pearson. Macnamara, J. (2014). Journalism and PR: Unpacking 'spin', stereotypes, and media myths. New York, NY: Peter Lang.

Macnamara, J., Lwin, M., Adi, A., \& Zerfass, A. (2015). Asia Pacific Communication Monitor 2015/16: The state of strategic communication and public relations in a region of rapid growth. Survey results from 23 countries. Asia Pacific Association of Communication Directors (APACD) and Helios Media. Retrieved from http://www.communicationmonitor.asia 
Macnamara, J. Lwin, M. Adi, A., \& Zerfass, A. (2016). 'PESO' media strategy shifts to 'SOEP':

Opportunities and ethical dilemmas. Public Relations Review, 42(3), 377-385.

https://doi.org/10.1016/j.pubrev.2016.03.001

Macnamara, J., Lwin, M., Adi, A., \& Zerfass, A. (2017). Asia-Pacific Communication Monitor 2017/18: Strategic challenges, social media and professional competencies - Results of a survey in 22 countries', Asia-Pacific Association of Communication Directors, Hong Kong. Retrieved from http://www.communicationmonitor.asia

Manning, P. (2001). News and news sources: A critical introduction. London, UK: Sage.

Marsh, I., \& Miller, R. (2012). Democratic decline and democratic renewal: Political change in Britain, Australia and New Zealand. Cambridge, UK: Cambridge University Press.

McChesney, R. (2013). Digital disconnect: How capitalism is turning the internet against democracy. New York, NY: The Free Press.

Media Standards Trust. (2018). Transparency initiative [Web page]. Retrieved from http://mediastandardstrust.org/projects/transparency-initiative

Miller, G. (1989). Persuasion and public relations: Two 'Ps in a pod"”. In C. Botan \& V. Hazelton (Eds.), Public relations theory (pp. 45-66). Hillsdale, NJ: Lawrence Erlbaum.

Negus, K. (2002). The work of cultural intermediaries and the enduring distance between production and consumption. Cultural Studies, 16(4), 501-515.

Over half your news is spin. (2010, March 15). Crikey. Report of Australian Centre for Independent Journalism. Retrieved from http://www.crikey.com.au/2010/03/15/over-half-your-news-is-spin

Pelley, S. (n.d.). Scott Pelley quotes. Retrieved from https://www.brainyquote.com/quotes/scott_pelley_537518

Peppercom and the Institute for Public Relations (IPR). (2017). Managing the digital age: A dialogue with CCOs and CMOs. Retrieved from http://www.instituteforpr.org/managing-digital-agedialogue-ccos-cmos-infographic

Poster, M. (1995). The second media age. Cambridge, UK: Polity.

PRCA (Public Relations Consultants Association). (2016). PR Census 2016. Retrieved from http://news.prca.org.uk/publications

Reichheld, F. (2008). The ultimate question: Driving good profits and true growth. Boston, MA: Harvard Business School Publishing.

Rosen, J. (2006, June 27). The people formerly known as the audience. PressThink [Web log]. Retrieved from http://archive.pressthink.org/2006/06/27/ppl_frmr.html

Ryan, M., \& Martinson, D. (1988). Journalists and public relations practitioners: Why the antagonism? Journalism Quarterly, 65(1), 131-140. http://dx.doi.org/10.1177/107769908806500118

Sachsman, D. (1976). Public relations influence on coverage of the environment in San Francisco area. Journalism Quarterly, 53, 54-60. https://doi.org/10.1177/107769907605300108 
Sallot, L., \& Johnson, E. (2006). Investigating relationships between journalists and public relations practitioners: Work together to set, frame and build the public agenda, 1991-2004. Public Relations Review, 32(2), 151-159. http://dx.doi.org/10.1016/j.pubrev.2006.02.008

Schönhagen, P., \& Meißner, M. (2016). The co-evolution of public relations and journalism: A first contribution to its systematic review. Public Relations Review, 42(5), 748-758. https://doi.org/10.1016/j.pubrev.2016.08.003

Sigal, L. (1973). Reporters and officials. Lexington, MA: D.C. Heath.

Sigal, L. (1986). Who? Sources make the news. In R. Manoff \& M. Schudson (Eds.), Reading the news (pp. 9-37). New York, NY: Pantheon Books.

Sissons, H. (2012). Journalism and public relations: A tale of two discourses. Discourse \& Communication, 6(3), 273-294. http://dx.doi.org/10.1177/1750481312452202

Stauber, J., \& Rampton, S. (1995). Toxic sludge is good for you: Lies, damn lies and the public relations industry. Monroe, ME: Common Courage Press.

Stegall, S., \& Sanders, K. (1986). Co-orientation of PR practitioners and news personnel in education news. Journalism Quarterly, 63(2), 341-347. https://doi.org/10.1177/107769908606300215

Taylor, M., \& Kent, M. (2014). Dialogic engagement: Clarifying foundational concepts. Journal of Public Relations Research, 26(5), 384-398. https://doi.org/10.1080/1062726X.2014.956106

Tilley, E., Hollings, J. (2008). Still struck in a 'love-hate relationship': Understanding journalists' enduring and impassioned duality toward public relations. in E. Tilley (Ed.), Power and Place: ANZCA 2008: Refereed proceedings of the Australian and New Zealand Communication Association Conference 2008, 9-11 July, Massey University, Wellington, New Zealand. Retrieved from http://www.anzca.net/conferences/past-conferences/35-anzca08.html

Turk, J. (vanSlyke). (1986). Public relations' influence on the news. Newspaper Research Journal, 7(4), 25-26.

Turner, G. (2010). Public relations. In S. Cunningham \& G. Turner (Eds.), The media and communications in Australia (3rd ed., pp. 207-216). Crows Nest, NSW: Allen \& Unwin.

Tye, L. (1998). The father of spin: Edward L. Bernays and the birth of public relations. New York, NY: Crown Publishers.

USC Annenberg. (2018). 2018 global communications report: The evolution of ethics. Los Angeles, CA: Author. Retrieved from https://annenberg.usc.edu/research/center-public-relations/globalcommunications-report

Verčič, D., \& Tkalac Verčič, A. (2016). The new publicity: From reflexive to reflective mediatisation. Public Relations Review, 42(4), 493-498. https://doi.org/10.1016/j.pubrev.2015.07.008

Walker, S. (1999). City editor. Baltimore, IL: The Johns Hopkins University Press.

WAN-IFRA [World Association of Newspapers and News Publishers]. (2017). World press trends 2017. Retrieved from http://www.wan-ifra.org/microsites/world-press-trends 
Waters, R., Tindall, N., \& Morton, T. (2010). Media catching and the journalist - public relations practitioner relationships: How social media are changing the practice of media relations. Journal of Public Relations Research, 22(3), 241-264.

Wernick, A. (1991). Promotional culture: Advertising, ideology and symbolic expression. London, UK: Sage.

White, D. (1950). The gatekeeper: A case study in the selection of news. Journalism Quarterly, 27, 383-390. Reprinted in L. Dexter \& D. White (Eds.) 1964, People, society and mass communications. New York, NY: Free Press.

White, C., \& Shaw, T. (2005, August). Portrayal of public relations in mass communication textbooks. Paper presented at the Association for Education in Journalism and Mass Communication, San Antonio, Texas.

Wilcox, D., \& Cameron, G. (2010). Public relations: Strategies and tactics (9th ed.). Boston, MA: Allyn \& Bacon.

Wilson, D., \& Supa, D. (2013). Examining modern media relations: An exploratory study of the effect of Twitter on the public relations-journalist relationship. Public Relations Journal, 7(3), 1-20.

Wright, D. (2005). We have rights too: Examining the existence of professional prejudice and discrimination against public relations. Public Relations Review, 31(1), 101-109. http://dx.doi.org/10.1016/j.pubrev.2004.11.015

Zawawi, C. (1994). Source of news: Who feeds the watchdogs? Australian Journalism Review, 16(1), $67-72$.

Zawawi, C. (2001). Feeding the watchdogs: An analysis of relationships between Australian public relations practitioners and journalists. Incomplete doctoral thesis, Queensland University of Technology, Brisbane, Qld.

Zerfass, A., Verčič, D., Verhoeven, P., Moreno, A., \& Tench, R. (2015). European communication monitor 2015. Creating communication value through listening, messaging and measurement. Results of a Survey in 41 Countries. Brussels, Belgium: European Association of Communication Directors (EACD), European Public Relations Education and Research Association (EUPRERA), and Helios Media.

1 Democracy in either a mature or emerging form is now the dominant political system in almost 200 countries worldwide (Marsh \& Miller, 2012).

2 The term gatekeeper was coined by social psychologist Kurt Lewin (1947) and was applied to editors and others who control access to and content of media by David Manning White (1950) and a number of other scholars since. 